\title{
Highlights in Museum Education
}

\author{
Leena Hannula \\ Sinebrychoff Art Museum, Helsinki; \\ University of Jyväskylä, Jyväskylä, Finland
}

\begin{abstract}
The aim of this paper is to research museum audience and its expectations, experiences, and influence on museum's practices at the Sinebrychoff Art Museum in Finland. The common idea is that museum pedagogy as a word creates easily an image of dusty, silent, and serious moment when the audience is forced to follow a lecture or a guided tour. The author's research questions are: (1) Museum as an institution—what are the limits and possibilities to create highlights for audience work? (2) How to look and talk about art for different audiences—also for non-visitors? (3) How can museum combine the knowledge of results and new technology to create more interesting approach for its audiences? Participants of the author's research are teachers, students, senior citizens, and colleagues from other museums. Besides the literature the author uses mixed methods by combining visitor questionnaires (made during last ten years) and qualitative research made by narrative methods. Interviews have been made by $\mathrm{H} 4$ recorder. The qualitative analysis is going to be made by Atlas.ti. The results will finally be analyzed in 2014. Until now, it has become clear that museum experience mostly starts from the web pages. What can we offer, how to give value to our museum audience?
\end{abstract}

Keywords: audience, museum pedagogy, social media, networking, technology-based programs

\section{Introduction}

After working 30 years with this subject the author decided to race her hand and participate to this long row of efforts to open the museum context with its contemporary audience at Sinebrychoff Art Museum in Finland. The author is working there as the Head of Education and an educational curator. The museum mentioned above is an interesting small piece of jewelry in the museum world —one could compare it with the Frick collection or Merchant's House in New York or Hallwylskamuseet in Stockholm. The original inhabitants of buildings have all been merchants, collectors, and art lovers whose cultural heritage nowadays is on charge of museum's professional staff. Balancing with collections and audience work the author is doing her doctoral thesis about museum audiences and their museum experiences to find out if there could be connection with needs of the audience and the pre-assumptions by museum staff. Besides the collection of Paul and Fanny Sinebrychoff, the museum context at Sinebrychoff Art Museum includes the family story, 21 other collections of the National Gallery, silver, china, and furniture and also the history of the Sinebrychoff brewery. As a small ancient palace with its history and stories in the middle of contemporary Helsinki, it has been a big challenge to create an interest towards contexts that for instance are concerning art in the year 1,300 or people who left the building in 1921s.

Leena Hannula, Doctoral Student, professor of Fine Arts, Head of Education, Faculty of Arts, University of Jyväskylä. 
Fanny Sinebrychoffpast away in 1921 and donated the collection to "Finnish people so that they didn't have to travel away from their home country”. Now it seems to be a harmful thought but for Paul and Fanny Sinebrychoff it meant enormous investments of money to make one of the most beautiful collections in Finland.

Museum "audience" has nowadays many categories—it is not always concerning only physical visitors. Though we use traditional ways in mediating arts we must learn to use new technology and social media. Museum context has been in an immense change-museum professionals have been facing the virtual and real life by collaboration with museum professionals, museology scholars, teachers, new technology education, and students. The main issues have been how to get people interested in museum programs and get exhibition experiences, or how to develop the digital museum context and online-teaching to homogenous, natural way of collaboration despite of global distances. To give some examples of some projects, the author will call them "highlights" because she has learned very much of each of the processes.

The author will follow three themes in her own process in describing why she has chosen to work as she do. The first is the studying period when the author did two diploma works of museum pedagogy. The second is the starting period as an educational curator with school projects and the third one concerns new technology-a never ending story. Mediation strategies and concerns of the fine arts are connected to traditions at daily museum work in contradiction to contemporary attitudes of new social collaboration. Networking both with international museums, schools, and museology students keep the museum education at Sinebrychoff Art Museum aware of its audience. The author has had great contacts both personally and virtually to international museums like AMNH (American Museum of Natural History) and MET (Metropolian Art Museum) in New York, thanks to professor Roberta Altman from the Bank Street College and William Crow who is the Head of Education in MET. Author and professor Herminia Din from Alaska has been a very important person by helping the author to find actual information of how to use new technology in museum education as well as William Crow who both have made books that have really been helpful in the author's work and doctoral studies.

\section{Quality or Quantity-Mixing Methods on the Backstage of Audience Work}

The author is working as the Head of Education at Sinebrychoff Art Museum (see Figure 1) and also as an educational curator with workshops. After studying music, art education, art history, museology, aesthetics, economics, culture management, and combining it to international work with Sinebrychoff Art Museum audience, or the author's museum education studies during her college time, the author nowadays has to mediate contexts of art in various ways. Every decade and culture has its own idea of storytelling. The author has been teaching art over 30 years both in schools and the museum. The author's mentor in the University of Arts and Design (known as Aalto University) was Head of Education MarjattaLevanto from the Ateneum Art Museum and the author would call the collaboration with her the first real highlight in the author's professional life. The author has done two diploma works to her, many interviews and been trained by her to learn to serve audiences in the best possible way using imagination, and always thinking of quality no matter to whom it concerns. It is not an easy task in museum world but through her methods the author has learned to create "highlights"- things that people want to remember. Her special interests were books and storytelling for children and children's weekends at Ateneum though the museum pedagogy was directed to all ages - the weekends mentioned before were very creative for guides, too. 


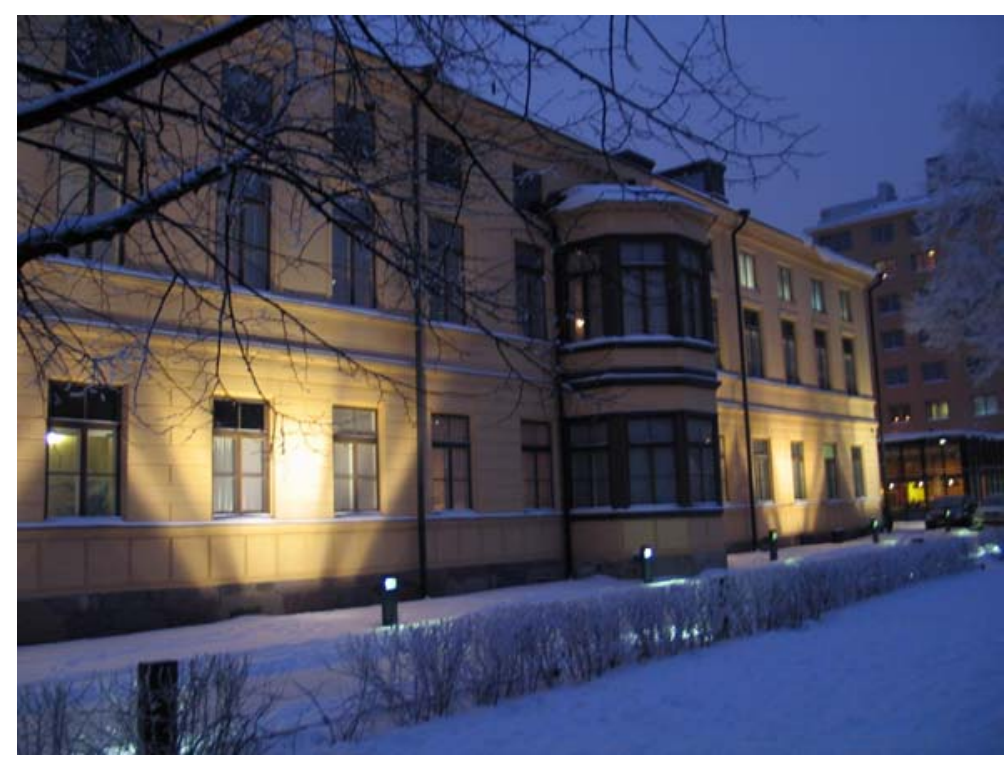

Figure 1. Sinebrychoff Art Museum, Helsinki, photo taken by Leena Hannula.

The world has changed but the same responsibilities are waiting for us in different forms. One of the biggest changes has been the change of direction from audience to museum. Sandell (2002) has written in his book Museum, Society, Inequality:

Within museum context, social responsibility requires an acknowledgement not only of the potential impact on social inequality, but also of the organizations' obligation to deploy their social agency and cultural authority in a way that is aligned and consistent with the values of contemporary society. (p. 18)

Can we keep the quantity without stepping on quality? In the year 2006, the author visited London's Engage congress and there it was obvious that the main task at the museum was to reach as many people as possible because of the funding. The author saw big school groups at museums and teachers keeping asking always the same question: "What is the Word?" and children giving the same answer: "Imagination!”. The same interaction with posing questions is concerning the social media and in online education programs, too. What are the questions we would like to ask and what we would like to know?

\section{The Reality Online-Good Practices With Good Partners at Sinebrychoff Art Museum}

There have been many misunderstandings concerning traditional approaches of museum education and maybe even more towards online-education. Collections which derive from the objects are often self-evident for the museums and are considered as media and they have traditionally been presented by curators, museum directors or guides. The audience however has great difficulties in recognizing or understanding the message because the collection does not bear a continuous one-to-one relationship with the source-material and therefore, mediators with other methods are needed. Besides, the museum audience today has changed the role of the museums towards more social equality in many ways. We have to consider the social agency of the museum, how the museums engage with social concerns and the idea of the character of inclusive museums which could be more relevant, effective, and useful to society in the future. The audience with its diverse richness can find a new approach for the collections-if we let it happen.

The biggest changes at the museum world have perhaps been the huge production of parallel stories 
connected to documents. Besides the scientific literature of arts, history and society there are many other sources that create a kind of illusion and another reality of the art world and its members. Fictive plays, former inhabitants, novels, marketing and advertising, portraits, and architecture have created their own story. The visitor is in the middle- what is real, can one separate facts from fictive stories, can a digital document of a visitor create something you can trust on? What things at the museum can fascinate visitors so much that they want to be documented as a part of museum life—Years at the Museum, not only one night... not only one visit—on line, too!

\section{Highlights in Museum Education-Audienceatwork}

One of the main features at the Sinebrychoff Art Museum is that collaboration with both colleagues and audiences concerns all ages, not only children. To get the results in finding tools to a pleasant museum visit, the author has planned many experimental projects at the museum with different audiences which have given new approaches to collections. Though the research is not ready, yet, one can consider that listening to the audience enriches the learning process and makes the museum experience more interesting. The fact that learning acquired in museums can be recalled long after the museum visit has been documented by Falk and Dierking (1995) and many others. Museum experienceis unique, authentic and long term. Here are some examples of long term projects to inspire to develop ideas further. To build a bridge between the past and today we have had several international and experimental museum-school projects which all can be mentioned as highlights.

\section{Audience Analysis—Benefits of Processing Collections Through Projects}

As a research method one of examples with adults is to use the narrative method: Let people speak freely without interruption. The digital equipments like H4-recorder, digital video or camera can be a little disturbing and influence for the result. That's why there must be confidence and the interviewer has to be able to ask relevant questions. Working with schools one of the main things in experimental museum education is to find reliable partners because projects need more engagement than a usual visit. The author has made two inspiring projects together with Riitta Pouttu from Turunsuomalainen yhteiskoulu (TSYK). She created a digitally documented school project as a part of Sinebrychoff Art Museum's Garderobe-project. Her school created dramatized, historically based narrative story telling project with self-made costumes of sausage, circulated material, waste paper... finally they had conquested the Brinkhall mansion house in Turku; students had made a historical drama project of von Bondsdorff family life. All this was carefully documented digitally also by students and Kimmo Kauvo (see Figure 2). The initiative for the project came in the first place from The National board of Education. Now it has been translated in Estonian language. The pictures became icons and the models felt very proud of their achievement. A small girl standing in a "Pompeij room corner" became the whole symbol of the exhibition (see Figure 3). Since that the pictures have circulated all over the places. So it was comfortable to approach a sensitive subject with a trustable colleague. The author would call this one of the second of highlights of my museum projects. 


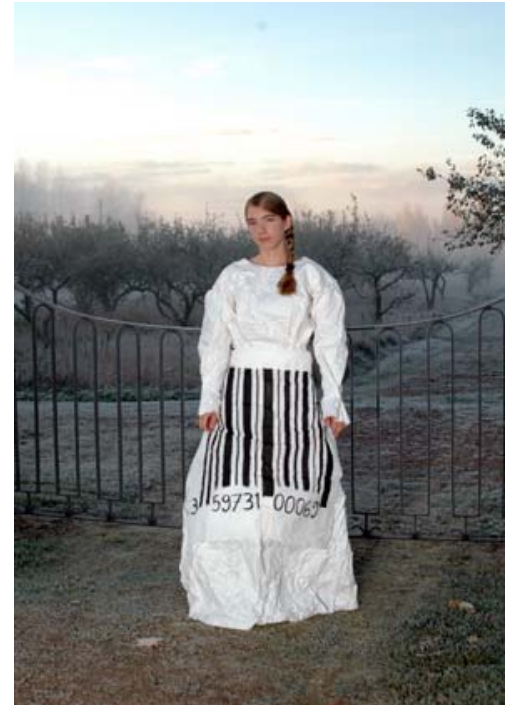

Figure 2. A Stripe Code Girl (TSYK), Brinkhall, picture taken by Kimmo Kauvo.

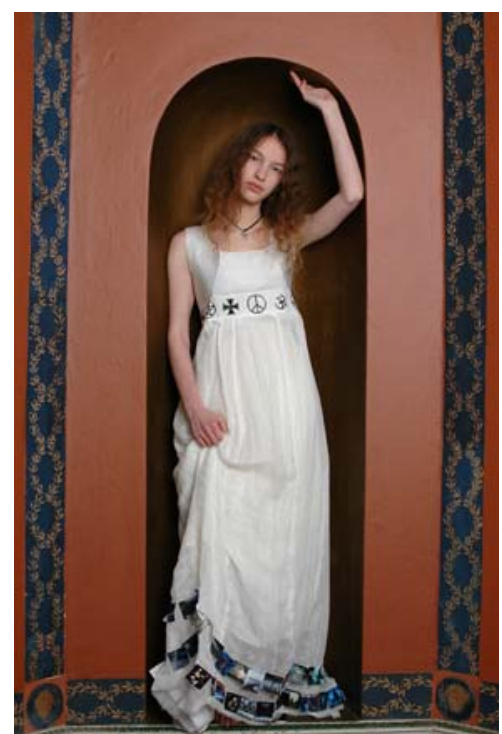

Figure 3. A Pompeiji- Hanna, TSYK, picture taken by Kimmo Kauvo.

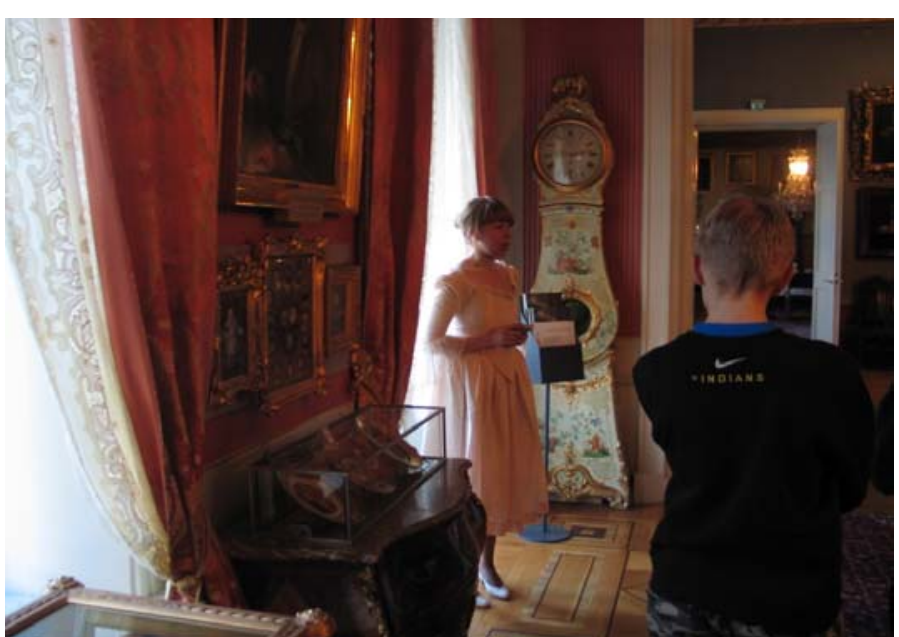

Figure 4. Along the Street, Kallion lukio’s student at Sinebrychoff Art Museum, photo by Leena Hannula. 
Along the Street brought other museums in collaboration (see Figure 4). Fictive plays, former inhabitants, novels, marketing and advertising, portraits, and architecture have created their own story. The visitor is in the middle - what is real, can one separate facts from fictive stories, can a digital document of a visitor create something you can trust on? To build a bridge between the past and today, we had another international school project called "Along the street”. There were four schools and three museums (the Hallwyll Museum in Stockholm (see Figure 5), the Helsinki City Museum and the Sinebrychoff Art Museum). Students were studying the history of Helsinki from archives, literature, and old photos from Sinebrychoff brewery, interviewing educational curators and finally we had an exhibition and plays. One inspiration came from New York. Today The Tenement Museum in New York has a mission to promote tolerance and historical perspective through the presentation and interpretation of the variety of immigrant and migrant experiences on Manhattan's Lower East Side, a gateway to America. They have drama tours in tenement buildings and good internet pages. In Finland, all the famous names we know today—Paulig, Fazer, Stockmann, and Huber—came from abroad during the same period, and like Sinebrychoff, are household names in Finland. Unlike the Sinebrychoff brewery itself, the museum's art collections and exhibitions are still strange and unfamiliar to the Finnish audience, even after 120 years - so there are a lot of challenges to attract visitors and make a museum visit understandable. From home-project gave a window to friendship (see Figure 6). Today when we speak about lifelong learning and education, it means pedagogy for all ages and groups. The day-care centers, senior citizens (see Figure 7), new ethnic groups, schools, and universities of education have been helpful with developing good methods for museum pedagogy and both its art education and accessibility. From Home project we had mixed age groups - students and senior citizens communicated in various ways, students wrote plays of home and these performances have been seen at the museums both in Finland and in Sweden. Schools had been chosen from the earlier two projects: Turunsuomalainenyhteiskoulu and Kallionlukio. About museums-we continued the fine collaboration with Hallwylskamuseet from Stockholm and got a new partner called Museet HEM from Turku. As a result the author would like to say that modern technology with all its possibilities gives value for the work at the museum. Very much has been done to increase the use of archives in both national and international levels. As it comes to visitors there is also much to be done. The documentation has proved that digital documentation has a customer value - the visit and efforts in focus have always got extra value and strengthened also the identity of a visitor.Senior citizens as highlights in museum education are not only a friendly cliché (see Figure 8). The author has been working for twelve years with a senior group which has mostly female members. The group is very homogenous though the members have changed. Inspired by Arts, Science, and Inquiry, teachers blended summer course in New York we made Ladies Night at the Museum with Roberta Altman. As the author mentioned before, one of the best examples of online teaching for the author has been The Teachers' Blended Summer Course-Art, Science, and Inquiry which were planned by MET and AMNH. Without Roberta Altman's enthusiasm and her kindness to draw the author in the middle of excellent collaboration between two fine museums: The Metropolitan Art Museum and The American Museum of Natural History the author would have been ignorant of the possibilities of new technology. The author has been very grateful to William Crow who has been supporting her from the distance while the author has tried to reach something of his and Herminia's fantastic work with online teaching (Crow \& Din, 2009). Crow and Din had made a three week-program with later "class reunion”. Altman and the author from the Sinebrychoff Art Museum were invited 
as observers of the project. Since that the author has been keen to develop new methods also in Finland. The author was studying all the courses of Social Media organized by Helsinki University and the Finnish Museum Association. Back to Ladies' night at the museum-it meant a lot of preparing for making questions and organizing online lectures but it was worth it—-the time difference between Finland and USA made a real "Night at the museum”.

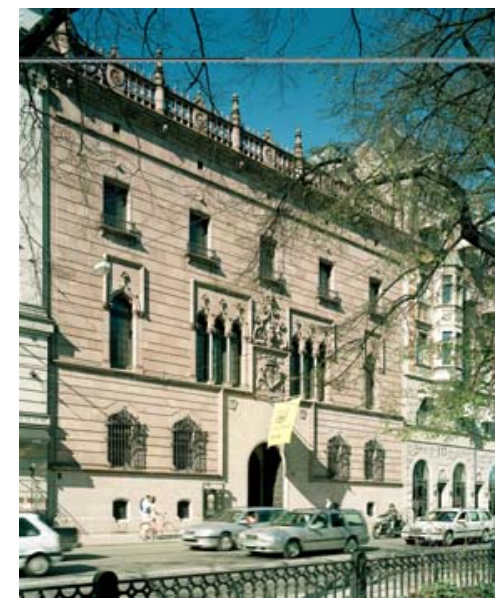

Figure 5. Hallwylska museet, Stockholm, Sweden.

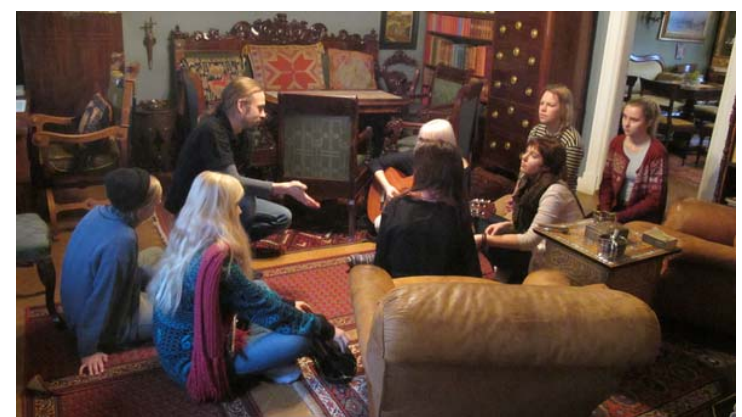

Figure 6. From home-project, Museet HEM, Turku, Finland.

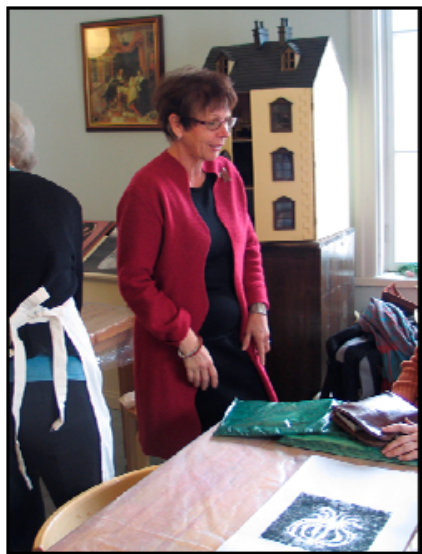

Figure 7. A senior lady at the Sinebrychoff Art Museum workshop. ${ }^{1}$

\footnotetext{
${ }^{1}$ The museum is a place but also a process. That process is one of discovering and learning about the world. In the museum it's manifested through exhibits and expeditions, but this process can take place just about anywhere ,Roberta Altman (AMNH, New York).
} 


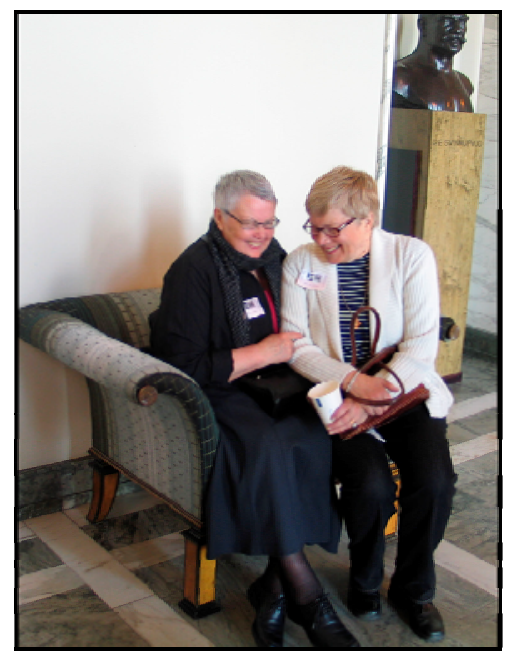

Figure 8. Senior ladies at the House of Parliament, by Leena Hannula.

\section{How to Mediate Your Story_Giving Value With Whom to Whom}

The main common fear in traditional museum environment has been that online communication makes museums useless. It is not possible to learn new technology alone and without support. Helsinki university has organized a course called MATK: a-pedagogy (museums, archives, science centers and libraries)—including the same ideas with a smaller scale as in Teachers’ Blended Summer course. In American summer course, William Crow has well explained the different tools for using digital environment for learning which partly are used in Scandinavia, too. Though the names change the functions will be comparable. The Finnish Museum Association has been kind and supported the author line to learn things that have been mentioned above. In the spring 2013, the author got a grant to travel to New York where she met Roberta Altman, William Crow, Herminia Din online and her previous contacts with Art Beyond Sight staff. The new contacts concerning VTS (Visual Thinking Strategies)—method in New York were Brooklyn museum. In Washington D.C., the method has been used at The National Museum of Women Artists and the National Gallery and we trained it also at the Finnish Embassy in Washington D.C., too. The author met museum educator Deborah Gaston from NMW (National Museum of Women in Arts) and museum educator Paula Lynn from NGA (National Gallery of Washington D.C.). At The Finnish National Gallery, there also has been the possibility to develop your own skills with audience work and now there has become more teams to create new contexts. The latest is made by a young generation to YouTube with the theme Art, Life, Love (Retrieved from http://www.youtube.com/watch?v=0RLyzktmtlQ).

Here are some of William Crow's examples of shared spaces and ideas: Online and blended museum-based teacher-training (teaching) needs innovative attitude. Of course we are talking about very different amounts of visitors and museum staff because there are 18,000 museums in USA, in Finland only 1,000. In spite of the difference of size, you can still pose the same questions: "Can I get access to collections and archives, can I get help from experts, can I be creative and do new things on basis of collections?”. There have been many experimental projects with different audiences which have given new approaches to collections. One of them was to give the museology students a possibility to make their YouTube video of the Sinebrychoff Art Museum building (Retrieved from www.youtube.com/watch?v=umQ9sUGgyLk), its collections and audience. We learned to use Google drive, share files and make a photostory and movies with music. During five years, there 
has been a long term series of lectures for museology students in Helsinki University. The author's task has been to be an innovator for students-how to make a museum omelette of elements mentioned before? The author had given a lecture at Helsinki University about new technology and participatory museum visits. Now it was time to let students show their own ideas of an ancient building.

To the end, the author would like to tell some examples when museum education has after invitation gone out of doors like to Suomenlinna where the famous baroque musicians and dancers from France and Italy have collaborated with children at Les Lumières-festival (1700s style). This year there was Raffaele Dessi (see Figure 9) who was the choreographer in Casanova-movie. Also the 300-year-old Qwensel-house in Turku found the common context of 1700s education with Sinebrychoff Art Museum. Qwensel House in Turku needed a script and drama—so finally they asked me to write the story with their needs. The result was that the author collaborated with Helsinki City Museum and copied their archives by hand (not a digital information), was acting a role of Maria Sederholm (a rich lady from Helsinki visiting her daughter Maria Pipping) and made ancient hairstyle. All this was on their webpages in a very humorous and nice manner. The author was asked to play a role of past Maria Sederholm who came to prepare young girls for the ball and help them to use a mouche and fans, learn dances and make hair-dressing (see Figure 10). Immediately after this the museum participated in Tall Ship Races-happening with sailor spirit (see Figure 11). Helsinki city had organized children's program - Annantalo Arts Centre and Sinebrychoff Art Museum made knots and sent signals with flags... we had 1,500 visitors in the park workshop during three days. The third project was on the contrary-a mass happening with visitors at the museum park-Tall Ship Races 2013 brought international boats and needed a lot of program for audiences. Sinebrychoff Park was reseved for children. We could give value to small customers and made the program as simple as we could to be able to serve them. It was also valuable for us - though it was a matter of quantity, too. In the last example, it was not a typical theme for the museum; knots, and flags but with acceptance and fine collaboration with others the audience and museum met successfully. The author's question is how to make a compact context and share experiences also after big happenings so that other teachers and educators could get ideas. How can a digital world give a hand-who from the real world can reach it? How can The National Gallery in Washington D.C be connected with Helsinki through museum pedagogy (see Figure 12)?

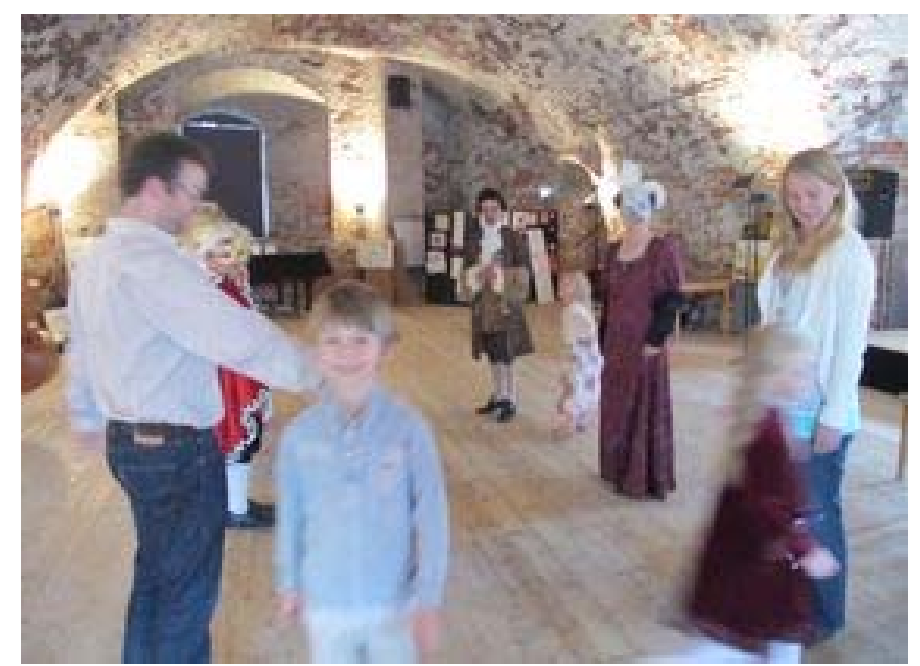

Figure 9. Raffaele Dessi at Suomenlinna, Les Lumières Festival 


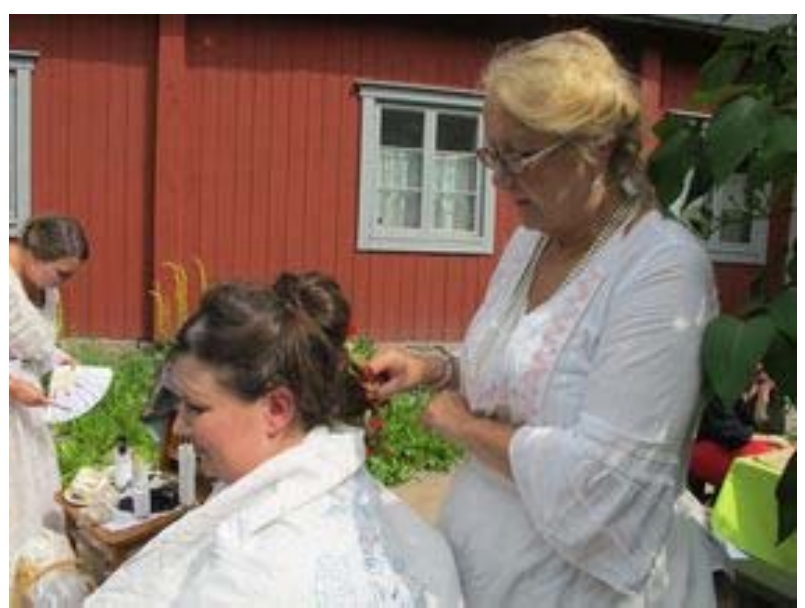

Figure 10. Hairdressin at Qwenel House, Turku.

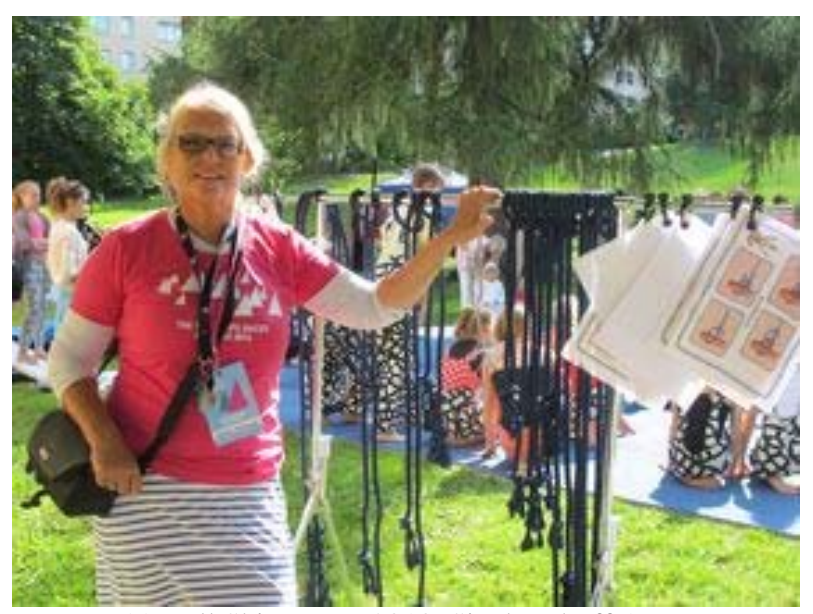

Figure 11. Tall Ship Races 2013, Sinebrychoff Art Museum.

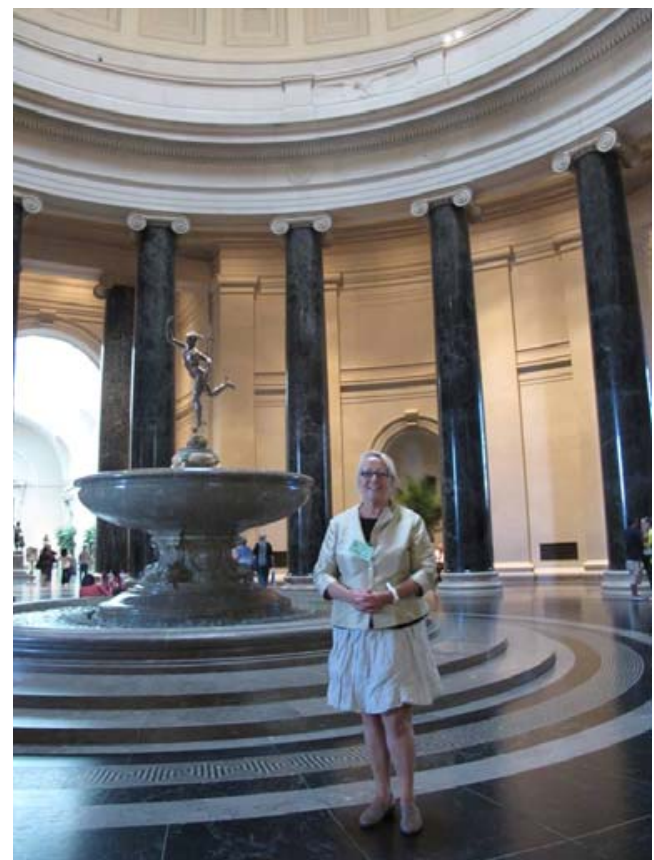

Figure 12. Leena Hannula at the National Gallery in Washington D.C.. 


\section{Conclusions}

As a result in still going process with the author's research of museum audience everyday work at the museum with its collections has not disappeared though we take the audience on focus - the work to preserve the cultural heritage for next generations is needed. With collections and professional knowledge, we can share information and cultural heritage, support identity and find new experiences. Globalization, modern technology with all its possibilities and professional staff give value for all the work at the museum. Technology as itself is not enough-it needs context and context can be given in many various ways. The main thing is to understand different audiences with different needs. We do not have to throw traditions because people love them; what we need to understand is not to stop the development and keep us open. There is plenty of room for diversity expressions and need for access to understanding contexts. Very much has been done to better the use of archives in both national and international levels. As it comes to visitors, not only a fear of being "good enough visitor" but the non-visitors, people with need of PDA (Personal Digital Assistant) or audio guide equipments and many other groups would need support to have courage to take the first step for entering the museum building. To get a highlight. It needs a social approach for audiences and a technology which unfortunately has prices that cannot be reached in most museums. The documentation has proved that besides visits a digital documentation and has a customer value - the visit and efforts in focus have always got extra value and strengthened also the identity of a visitor. The author will be very curious of the results when using qualitative analysis program Atlas.fi. Can a program make us see more than we already know?

\section{References}

Barrett, T. (2003). Interpreting art, reflecting, wondering, and responding. New York: Mc Graw-Hill.

Burnham, R., \& Kai-Kee, E. (2011). Teaching in the art museum-Interpretationas experience. Los Angeles: J. Paul Getty Trust.

Crow,W. B., \& Din, H. (2011). All TOGETHERNOW: Museums and online collaborative learning. Washington D.C.: The AAM Press of the American Association of Museums.

Crow, W. B., \& Din, H. (2009). Unbound by place or time, museums and online learning. Washington D.C.: AAM Press.

Din, H., \& Hecht, P. (2007). The digital museum, a think guide. Washington D.C.: AAM Press.

Falk, J. H. (2009). Identity and the museum visitor experience. Walnut Creek: Left Coast Press.

Falk, J. H., \& Dierking, L. D. (2002). The museum experience. Washington D.C.: Howell's House

Hein, G. E. (1998). Learning in the museum. London and New York: Routledge.

Hopper-Greenhill, E. (1995). Museum, media, message. London and New York: Routledge.

McLuhan, M. (1964). Understanding media. London and New York: Routledge and Kegan Paul Limited.

Sandell, R. (2002). Museums, society, inequality. London and New York: Routledge. 